Kresna Social Science and Humanities Research

Proceedings of the International Conference On Ummah:

Digital Innovation, Humanities And Economy (ICU: DIHEc) 2020

https://doi.org/10.30874/ksshr.14

\title{
Strengthening Religious Characters: Efforts to Save Indonesia
}

\author{
Santy Andrianie, Laelatul Arofah, Restu Dwi Ariyanto \\ santyandrianie@unpkediri.ac.id, laelatularofah@unpkediri.ac.id, \\ restudwiariyanto@gmail.com \\ Universitas Nusantara PGRI Kediri, Jl KH. Ahmad Dahlan 76 Kediri \\ Universitas Nusantara PGRI Kediri, Jl KH. Ahmad Dahlan 76 Kediri \\ Universitas Nusantara PGRI Kediri, Jl KH. Ahmad Dahlan 76 Kediri
}

\begin{abstract}
The rapid development of the world must be balanced with strengthening the character of the Nation so that the younger generation does not lose the direction. Social problems caused by changes in cultural values among adolescents is one indicator of the declining character of the Indonesian nation. This condition is an alarm to improve the character of Indonesia from an early age. Through the Ministry of Education and Culture, the government has launched a program for Strengthening Character Education which was implemented early. Religious character becomes the main character that is proclaimed by the government to strengthen the character of the younger generation. Religious character has an important role as a director, guide, and balancer of other characters in students, so this character needs to be improved early on. The purpose of this study is to describe the role of religious characters in supporting the identity of the Indonesian nation's character. The method used is literature review. The results of this study will provide an overview of strategic steps to strengthen the religious character of senior highschool students.
\end{abstract}

Keywords: religius, character. 


\section{Kresna Social Science and Humanities Research}

Proceedings of the International Conference On Ummah:

Digital Innovation, Humanities And Economy (ICU: DIHEc) 2020

https://doi.org/10.30874/ksshr.14

\section{Introduction}

Educating the nation's life is one of the noble ideals of the Indonesian nation in the preamble to the 1945 Constitution. The previous nation generationsrealizethe importance of the good generationis expected to be able bring Indonesia more advanced in the international. This concept has been realized in national education activitiesto empowerment young generation more advanced and already compete in the international world.

The development of science and technology are like two sides of a coin that must be accepted by the Indonesian people. Universal exchange of information made easier, must be balanced with the skills of the younger generationto fortify themselves and filter out information from outsideso as not to lose their Indonesian nation identity. Furthermore, inability younger generation to filter outside information and culture for imitationmake a loss of the uniqueness of a society, local wisdom, and creating a universal culture that will just destroy the balance of the world.

Strengthening character is one of things that are considered effective in solving the increasing cases of moral and value violations that are happening among Indonesian teenagers today. Indonesia is a multi-ethnic and multi-cultural country that strongly emphasizes the value of mutual respect and respect for each other. In addition, Indonesia is also known as a religious country. Although Indonesia is known as a country that has a society with various beliefs, able to harmonize it and creating a peaceful and unpretentious life.

Ease of fast exchange of information, knowledge and culturenot followed by equipping younger generationfilter foreign information and culture well was resulting in the erosion of the original character of the Indonesian nation. This phenomenon creates a new culture that incompatible with culture and beliefs that exist in Indonesia. This condition has resulted in increasing violations of norms, values and rules in Indonesia.

Follow up on this condition, the government has launched character education which is internalized in all aspects of educational activities in Indonesia. Character education is the main goal that is as important as education that emphasizes theory. Government realizes that it is not enough to educate the nation's life by simply equipping the future generations with qualified knowledge and skills, but also to instill a strong Indonesian character in the younger generation, so that they do not lose their roots as Indonesian people.

Hamid (2017) explains that the government in realizing character education through Strengthening Character Education (PPK) is integrated in the National Movement for the Mental Revolutionwhich is a changes in ways of thinking, behaving, and acting for the betterwhich is integrated in the National Movement for the Mental Revolution, which is a change in ways of thinking, behaving, and acting for the better. This program is designed to respond to the decline in morale of the nation's generation and to realize the 21 st century skills needed by students to realize the competitive advantage of the 2045 golden generation: Character Quality, Basic Literacy, 4C Competence (Critical Thinking an Problem Solving, Creativity, Communication Skills, and Ability to Work Collaboratively "(Kemendikbud, 2017).

Through the character education strengthening program (PPK), the government through the ministry of education and culture internalizes Indonesian characters into all aspects of teaching and learning education activities in schools. These characters are: religious character, integrity character, nationalist character, independent character and cooperation character. Through this character education, hoped that Indonesia's character as root of nation's life will not fade in younger generation 


\section{Kresna Social Science and Humanities Research}

Proceedings of the International Conference On Ummah:

Digital Innovation, Humanities And Economy (ICU: DIHEc) 2020

https://doi.org/10.30874/ksshr.14

A nation can be said to be advanced not because of its age and duration of independence, population and natural resources, but nationcharacter (Cahyono, 2015). This opinion reinforces the need to launch character education from an early age. Strengthening character education that has been given from an early age is expected ableto be positive in facing future world era, so that younger generation is able to act and behave wisely. Aulia (2016) explains that character plays a very important role in national civilization. Society has high hopes for nation's future generations, so we must prepare the next generation to have the quality of knowledge, able to act and responsible for decisions they makes. This opinion is supported by Samani \& Haryanto (2012) which explains that a strong character will become a fundamental view that is able to provide a peaceful life and form a world full of goodness and virtue, and free from violence and immoral actions for mankind.

Samani \& Hariyanto (2012) explain that character is considered the values of human behavior related to God Almighty, oneself, others, environment and nationality which are actualized in thoughts, feelings, words, attitudes, and actions based on norms that apply around it. This opinion refers that character is not only related to individual as self but also relationship between humans with gods and relationships humanwith each other.

Etymologically, the word character comes from Greek "charassein" which means "to engrave". The word "to engrave" can be translated engraving, painting and scratching. Humans are likened to being born like a white paper which will later be colored by the environment which is the place of worldly education. If character is defined as engraving, painting and scratching, it means that character is a process of forming individuals. what an individual will become and what color the individual will be will depend on the engraving, painting and scratchingthat will be implanted in that individual

Arikunto (2010) defines character as a collection of values that lead to a system, which underlies the thoughts, attitudes and behaviors displayed. Character is defined as a set of values, meaning that there are benchmarks that will serve as a character reference and serve as the basis for assessing an individual based on decisions or actions performed by that individual

Character education is an continuous process. Family as a child's first school, will give the basic color in formation of individual characters. However, educational institutions also have an important role in shaping a person's character through academic and social education activities that occur in the educational process in schools.

Bohlin, et al. (2001) explained that character education is an effort to encourage students to grow and develop with the competence to think and stick to moral principles in their lives and have courage to do right even faced with various challenges.Meanwhile, Raharjo interprets character education as a holistic educational process that connects moral dimension with social realm in students life as foundation for the formation of a quality generation that able to live independently and has the principle of a truth that can be accounted. Character education is defined as process to prepare individuals able to live in a societythat has rules and values responsibly. Therefore, strengthening character education is considered very relevant to overcome the increasing moral crisis in Indonesia

In human life, character education process has been experienced by individuals from an early age to adulthood with experiencing various continuous stages (Aeni, 2014). Stages of character development in individuals are influenced by various factors, both internal and external factors. External factors that influence are the environment, family and school environments, such as interaction with peers and learning (Hurlock, 2006). 


\section{Kresna Social Science and Humanities Research}

Proceedings of the International Conference On Ummah:

Digital Innovation, Humanities And Economy (ICU: DIHEc) 2020

https://doi.org/10.30874/ksshr.14

Religious refers to religion or belief. Religious character is absolute and eternal because it comes from beliefs that humans have and are universally agreed upon according to belief groups. Every religious community is expected to be responsible for their beliefs. That is, they are said to have good religious character if they make the values of their beliefs as the basis for making decisions and behaving responsibly.

A strong religious character is the basis for students to become people who can control themselves against negative things (Utami, 2014). In the context of life, expertise in science is considered meaningless without good character. A strong religious character will contribute to every individual decision making. Religious values will provide signs of right or wrong, good or bad, can do or can't do,appropriate or inappropriate for something done by individuals. With the stronger religious character, it can make a person more able to control himself against things that are negative.

Religious character can be taught considering the lifelong stages of character education and religious understanding and practice can be improved. Therefore, it is necessary to create a habitual condition. The habituation of applying religious characterthat is carried out continuously and continuously in various aspects of life will create a new culture within the individual. This habit will gradually strengthen the presence of a religious character in the individual.

Seeing the central role of religious character in giving consideration to human life, it is considered that the religious character is able to become a director, guide, and balance of characters in a person. Therefore, religious character becomes the main character that needs to be improved in order to overcome the moral problems that occur in Indonesia. Increasing religious character among the younger generation, it is hoped that it will be able to prepare a golden generation of Indonesia that is able to realize Indonesia as a quality country not only academically, but also in character.

\section{Method}

\subsection{Research methods}

The research method used in this article is literature study. This method is carried out by looking for theories from articles and journals that are considered relevant to religious characters. Creswell $(2014 ; 40)$ explains that literature review is a written summary of articles from journals, books, and other documents that describe theory and information both past and present organizing literature into topics and documents needed. Thus, researchers use articles, journals, and books as sources to examine research topics for later analysis.

\subsection{Research subject}

The research subjects used in this research are articles, journals and books related to religious character and efforts to strengthen religious character.

\subsection{Data collection}

Data collection in this study used primary and secondary data. Primary data using obtained from observation activities.Secondary data using books, articles, journals, scientific papers, and other documents related to research topic. The data was relevant with research topicthen archived for in-depth studyso that later they can be used in data analysis activities. 


\section{Kresna Social Science and Humanities Research}

Proceedings of the International Conference On Ummah:

Digital Innovation, Humanities And Economy (ICU: DIHEc) 2020

https://doi.org/10.30874/ksshr.14

\subsection{Data analysis method}

The type of data analysis method used is descriptive analysis. The data obtained in data collection activities were then analyzed using descriptive analysis techniques. Descriptive analysis technique is a method that serves to describe or provide an overview of the object under study through data or samples that have been collected as is without analyzing and making conclusions that apply to the general public (Sugiono, 2009: 29). Thus, the data that has been obtained are arranged systematically to be factually described and analyzed. This analysis activity is not only to describe the facts obtained but also to provide explanation and understanding

\subsection{Research procedure}

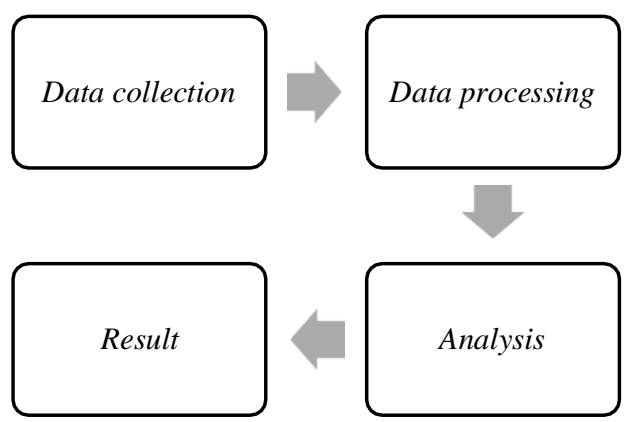

Fig. 1.Research stages

The stages carried out in this study are as follows:

2.5.1 Data collection

Based on data sources, in this study there are two types of data, primary data and secondary data. Primary data obtained through observation activities. Observation activities are carried out by observing character strengthening activities for children in various life settings, both at school and at home. Secondary data is documents obtained through literacy which journals, articles, books, and other scientific works

2.5.2 Data processing

Primary and secondary data obtained during the data collection stage are then archived to be arranged systematically so that data can be used for descriptive analysis. The data that has been compiled are then reviewed to ensure data completeness, data coherence, clarity of meaning, and harmony of meaning between data so that they can be used as the basis for data analysis activities.

\subsubsection{Data analysis}

Primary and secondary data that have been arranged at the data processing stage are then analyzed using descriptive analysis methods. This method begins by systematically arranging the facts which are the findings from primary and secondary data sources. These facts are then analyzed in-depth. The analysis is carried out not only describing the facts found from the observation and literature review, but also providing the required explanation and understanding. Thus, these facts can become a strong foundation in compiling research results.

\subsubsection{Result}

The results in this study are a description of steps to strengthen religious character that can be applied in schools so as to support the creation of future generations who have strong religious characters.

\section{Result and Discussion}

Character education is the main focus in Indonesia's current educational goals. The development of technology and science becomes two sides of the coin for the younger generation of Indonesia in welcoming the golden generation of 2045. Technological advances that are not matched by the ability of the Indonesian generation to filter foreign cultures to be 


\section{Kresna Social Science and Humanities Research}

Proceedings of the International Conference On Ummah:

Digital Innovation, Humanities And Economy (ICU: DIHEc) 2020

https://doi.org/10.30874/ksshr.14

adopted in the order of everyday life are gradually eroding the original Indonesian character. become the identity of the nation.

\subsection{Adolescent character description}

The knowledge and skills of generations $\mathrm{Y}$ and Z, who are currently starting to enter the adolescent age group, are better than those of the previous generation. Adolescents have been able to distinguish concrete from abstract, explore, test hypotheses, and have broad thinking horozones. High curiosity and supported by easy access to information also support their paradigm of thinking so as to form new ways of thinking.

Many indigenous indigenous cultural values have begun to be abandoned. This can be seen from the beginning of the shift in youth's "preference" for foreign cultures which are considered more advanced and more interesting to follow. This condition will worsen if environmental conditions do not support a person to instill Indonesian character in himself or what is commonly known as lazy.

The increasing number of violations of morals and values that occur in Indonesia is also largely influenced by the entry of foreign cultures that are not able to be filtered by the younger generation. Foreign culture cannot automatically be applied in Indonesia considering that Indonesia is a rule of law and has a distinctive eastern culture. A study conducted by the National Commission on Violence against Women, shows that in the past 12 years, violence against women has increased by $792 \%$. When compared to 2019 cases of violence against girls in 2020 increased by $65 \%$. Cases of violence against children were dominated by incest and sexual violence. These causes of violence are mostly carried out by close people and family members. The family, which should be able to protect their closest ones, is currently considered to be the party that must also be watched out for cases of violence. Much of this is due to their inability to control their emotions and desires that make their closest people victims of violence and even sexual violations. The low level of religious character is a contributing factor to the increase in sexual violence in Indonesia. (https://www.komnasperempuan.go.id/read-news-siaran-pers-dan-lembar-fakta-komnasperempuan-catatan-tahunan-kekerasan-terhadap-perempuan-2020).

In addition to the problem of violence, the problem of drug abuse, especially among adolescents, is also increasing, World Drugs Reports 2018 published by the United Nations Office on Drugs and Crime (UNODC), states that there are 275 million people in the world or $5.6 \%$ of the world's population (age 15). -64 years) have used drugs. Meanwhile, the number of drug abuse among students in 2018 (from 13 provincial capitals in Indonesia) reached 2.29 million people. One of the groups of people who are prone to being exposed to drug abuse are those in the age range 15-35 years or the millennial generation. Adolescent self-control in terms of drug abuse is also decreasing so that they are easily influenced by their association to use drugs. This shows the lack of discipline, patriotism and religious character of students so that they are unable to fortify themselves in doing things that are prohibited by law and religion. (https://bnn.go.id/penggunaan-narkotika-kalangan-remaja-meningkat/). 


\section{Kresna Social Science and Humanities Research}

Proceedings of the International Conference On Ummah:

Digital Innovation, Humanities And Economy (ICU: DIHEc) 2020

https://doi.org/10.30874/ksshr.14

The bullying case that occurred at SMPN 16 Malang City is also a fact that cannot be ruled out in the decline in the character of adolescents in Indonesia. The bullying that occurred was committed by classmates, Scout extra-curricular friends, and friends of the Islamic Da'wah Agency at school with 7 perpetrators. Perpetrators and victims are close friends and often interact. The victim was a quiet figure, he was often dropped in the mosque and then sat on and stepped on. This bullying not only resulted in psychological trauma, but also resulted in physical injury that required amputation of his fingers. This condition is a national concern for the younger generation. Decreasing feelings of empathy and faith among teenagers is something that cannot be ignored and needs to be resolved immediately. The neglect of the decline in religious character which results in increased violations and acts of bullying among students will become an iceberg for Indonesia's future which will destroy the future of the nation. (https://www.cnnindonesia.com/nasional/20200205140320-20-471871/diduga-korbanbullying-jari-siswa-smp-di-malang-diamputasi)

The description of the case above is an alarm for the Indonesian nation to immediately seek a formula to prevent moral violations among the nation's generations. One of the things that can be used as an alternative solution is character strengthening activities. A strong character in an individual is able to make someone make wise decisions so that moral violations do not increase.

\subsection{Character Education}

Khan (2010) explains that character education is a process of activity that leads to improving the quality of education and the development of character and moral values that always teaches, guides, and fosters every student to have intellectual competence, character and skills. The explanation above emphasizes that in character education, children are not only taught character but also knowledge. Moral education is also intended so that they do not commit immoral acts or endanger themselves or others.

Character education has been introduced to children from an early age. The first character education teachers are parents. In childhood, they have been shown to be do-andnot-do behavior, they are also taught to distinguish good and bad and how to behave according to the values taught in the community group. Reaction events can occur early on if the child's environment (family) is unable to instill character education activities properly.

At a higher age, the child's social life environment will be wider. They will meet a lot of friends who come from various family environments. This condition can be good if the child meets and mingles with people who have good character, or it will have a negative impact if the child meets and mingles with friends who have negative characters, therefore parents must help children to filter their interactions. .

At the level of education, the children's social interactions will be more widespread. The existence of a new environment and rules in educational settings will also require children to train and strengthen characters that will be useful in their lives. For example, in school students are bound by rules that must be obeyed, therefore they must be able to improve the character of their discipline as a commitment of a student. In terms of learning activities, students are united in a heterogeneous group, meaning that in one group there will be children who have various characters, but they are required to be able to cooperate with one another, filling in gaps in the group so that they can learn optimally together.

Realizing the importance of strengthening character, the government has initiated character education in formal education settings. This program is aimed at preventing the erosion of the original character of the Indonesian people. Through the Ministry of Education and Culture, educational activities must be character-based, meaning that in all learning activities, they must be loaded with the original national characters that have been proclaimed 


\section{Kresna Social Science and Humanities Research}

Proceedings of the International Conference On Ummah:

Digital Innovation, Humanities And Economy (ICU: DIHEc) 2020

https://doi.org/10.30874/ksshr.14

in the Strengthening Character Education (PPK) program which has 5 (five) main values, namely religious, nationalist, independent, mutual cooperation, and integrity. Each value has characteristics that must be developed in order to change the way of thinking, behaving, and acting for the better.

The implementation of strengthening character education that can be done in schools, such as: shaking hands when coming to school, greeting when meeting, starting learning activities by praying, carrying out state activities, implementing rules at school, please help, and so on. Through these familiar activities, it is hoped that students will be able to internalize themselves so that they become characters that are applied in their lives. Thus, it is hoped that this strengthening will be able to shield the influence of foreign cultures which will gradually erode the original character of the Indonesian people.

\subsection{Strengthening religious character to save Indonesia}

Religious is the first character proclaimed by the government in the character strengthening program. As the most universal character where the basis for this character is a person's belief in god, this character becomes the most basic guide for individuals to make decisions in their life. The position of religious character as an individual's life guide is able to make this character a balance of characters in a person.

Character is a skill that can be trained. This means that character can be strengthened through lessons if implemented correctly. Through learning, habituation, and routine, it is hoped that a character will stick and become a strong guide in a person. Thus, the rang will be able to control himself not to do bad things.

Strengthening character education is deemed appropriate to be chosen as a solution to moral problems that occur in Indonesia. If someone has a strong religious character, it is hoped that they will use their religious values and rules to make decisions. This of course will prevent negative actions from happening. By strengthening religious character, it is hoped that the good characters instilled in a person will also increase.

Strengthening character education cannot stand alone by only being carried out in an educational setting in schools. Parents and society must play an active role in supporting the success of strengthening character education. This is because children only spend an average of 7 hours per day at school, while most of their time is spent in the family or community. Thus, strengthening character education by training it on an ongoing basis can have maximum success.

Strengthening religious character starts from the family environment by getting used to praying before starting activities, carrying out worship in an orderly manner, helping each other, forgiving each other, and other religious activities in accordance with the religious values of the religion they profess. In the family setting, parents must have a role to play in instilling a religious character. The role of parents is not enough just to remind, give suggestions, or criticize, but parents also have to play an active role in accompanying or setting an example so that children are able to improve their religious character.

The community environment also has a big role in creating a generation that has a strong religious character. Allowing norm violations to become behavior that contributes to the increase in social violations that occur in society. Therefore, the community must be more sensitive and caring, because people's ignorance will plunge the younger generation into ignorance of social violations. Reminding when adolescents bully, violating cultural and moral norms, and reminding children who violate religious norms must be done if we want the progress of our nation in future generations.

School as a place for children's education also has an equally important role. By carrying out the lofty aspirations to educate the nation's life, schools have an important role in 


\section{Kresna Social Science and Humanities Research}

Proceedings of the International Conference On Ummah:

Digital Innovation, Humanities And Economy (ICU: DIHEc) 2020

https://doi.org/10.30874/ksshr.14

strengthening the inculcation of religious character in students. As parents in schools, teachers are not only required to provide knowledge and skills through learning activities, but must also be able to provide examples of religious behavior in students. considering that character can be trained, the low commitment of the teacher to strengthen religious character will also have an impact on decreasing the religious character of students. Therefore, teachers must be able to commit to strengthening religious behavior by carrying out learning activities and role models in students. Internalization of religious character in teaching and learning activities is currently well done, but it still needs to be improved by implementing additional religious activities outside of learning activities which are expected to be able to improve students' religious character such as routine social service activities, congregational sunnah worship, lecture activities. religion and religious discussions, and other religious activities that are carried out regularly so that religious character can be strengthened.

\section{Conclusions}

Character education is the foundation needed to create a future generation that is superior but still grounded by upholding the wisdom of the Indonesian people. Through character education, Eastern distinctive values will be maintained and serve as guidelines in the life order of the Indonesian nation. This condition will keep Indonesia known for its distinctive cultural characteristics, thus making it a differentiator from other country's characters.

Religious character is a basic character that must be possessed by every individual. The diverse demographic and geographic conditions of Indonesia and Indonesia's identity as a prularist country have resulted in groups of Indonesian society having a unique character. Religious character is a counterweight to the various indigenous characters that a person has. Religious character, as the most universal character and becomes the basis for humans in determining their life choices, must be strengthened so that they are able to support other characters in a person so that other characters can develop positively.

The first religious character education someone gets in a family education setting. If you want religious character to develop optimally, then the family must be able to build this character from an early age. In the educational setting, since the pre-school level of education, a lot of religious character has been instilled. This strengthening of religious character will continue to increase according to the age development task of students and based on the age of students. Therefore, collaboration between parents and educators needs to be built to create a strong religious character. 


\section{Kresna Social Science and Humanities Research}

Proceedings of the International Conference On Ummah:

Digital Innovation, Humanities And Economy (ICU: DIHEc) 2020

https://doi.org/10.30874/ksshr.14

\section{References}

[1] Arikunto, S. Prosedur Penelitian Suatu Pendekatan Praktik. Jakarta: Rineka Cipta; 2010.

[2] Aeni, A. N. Pendidikan Karakter untuk Siswa SD dalam Perspektif Islam. Jurnal Publikasi. 2014; 1(1): 50-58.

[3] Aulia, Listya Rani. Implementasi Nilai Religius dalam Pendidikan Karakter bagi Peserta Didik di Sekolah Dasar Juara Yogyakarta. Jurnal Kebijakan Pendidikan. 2016; 3(5): 314-323.

[4] Bohlin, K.E; Farmer, D; \& Ryan, K. Building Character in School: Resource Guide. San Francisco: Jossey-Brass; 2001.

[5] Bnn.go.id. (30 April, 2020). Penggunaa Narkotika Kalangan Remaja Meningkat. Diambil pada 1 Agustus 2020.https://bnn.go.id/penggunaan-narkotika-kalangan-remajameningkat.

[6] Cahyono, Hadi. "Pola Pengembangan Pendidikan Karakter Siswa (Sebuah Studi Di Sdn 1 Polorejo)." Jurnal Dimensi Pendidikan Dan Pembelajran. 2015.

[7] Cresswell, J. W. Qualitatif Inquiry and Research Design. Sage Publication, Inc: Californis; 1998.

[8] Cnnindonesia.com (30 April, 2020). Diambil pada 1 Agustus 2020. https://www.cnnindonesia.com/nasional/20200205140320-20-471871/diduga-korbanbullying-jari-siswa-smp-di-malang-diamputasi.

[9] Hamid, A. Pendidikan Karakter Berbasis Pesantren: Pelajar dan Santri dalam Era IT dan Cyber Culture. Surabaya: IMTIYAZ; 2017.

[10] Hurlock, E. B. Psikologi Perkembangan. Jakarta: Erlangga.

[11] Kemdikbud.go.id. (17 Juli, 2017). Penguatan Pendidikan Karakter Jadi Pintu Masuk Pembenahan Pendidikan Nasional. Diambil pada 23 April, 20 dari https://www.kemdikbud.go.id/main/blog/2017/07/penguatan-pendidikan-karakter-jadipintu-masuk-pembenahan-pendidikan-nasional.

[12] Khan, Yahya. Pendidikan Karakter Berbasis Potensi Diri. Yogyakarta: Pelangi Publishing; 2010.

[13] Komnas perempuan.go.id. (30 April, 2020) .Siaran Pers dan Lembar Fakta Komnas Perempuan Catatan Tahunan Kekerasan terhadap Perempuan 2020. Diambil Pada 1 Agustus 2020. (https://www.komnasperempuan.go.id/read-news-siaran-pers-dan-lembarfakta-komnas-perempuan-catatan-tahunan-kekerasan-terhadap-perempuan-2020).

[14] Samani, Muchlas \& Hariyanto. Pendidikan karakter. Bandung: PT Remaja Rosdakarya; 2012.

[15] Sugiyono. Memahami Penelitian Kualitatif. Alfabea: Bandung; . 2014.

[16] Utami, A. T. (2014). Pelaksanaan nilai religius dalam pendidikan karakter di SD Negeri 1 Kutowinangun Kebumen. Skripsi tidak dipublikasi. Universitas Negeri Yogyakarta. 